\title{
CHEST LEAD CHANGES AS THE SOLE ELECTRO- CARDIOGRAPHIC EVIDENCE OF HEART DISEASE
}

\author{
BY \\ RALPH M. SUSSMAN AND ABRAHAM LIEBERSON \\ From the Medical and Electrocardiographic Departments of Beth Israel Hospital, New \\ York City, U.S.A. \\ Received September 2, 1940
}

Within the past seven years the fourth lead, as originally introduced by Wolferth and Wood (1932) after the experimental studies of Wilson et al (1931), has been used with increasing frequency as a routine cardiographic procedure (Lieberson and Lieberson, 1932-33; Hoffmann and De Long, 1933; Katz and Kissin, 1933; Goldbloom, 1934; and Master, 1934). It has occasionally come to the fore as the exclusive sign of myocardial infarction involving the so-called " silent" areas of the heart, regions not adequately explored by the standard leads. Its value as the sole electrocardiographic sign of myocardial disease, not due to coronary thrombosis or sclerosis, has not received much attention. We therefore decided to review a large series of cardiograms to determine how often positive findings in the fourth lead are the only evidence of myocardial disease, i.e. where there are no revealing signs in the standard leads.

Four thousand four-lead cardiograms taken at Beth Israel Hospital from January 1, 1936, to January 1, 1939, were studied. Only those records were finally selected in which the standard leads were within normal limits and the præcordial leads were unquestionably abnormal as evidenced by (1) an absent $\mathrm{R}$ wave or an $\mathrm{R}$ wave of less than $2 \mathrm{~mm}$., (2) a depressed or significantly elevated RS-T segment ( $2 \mathrm{~mm}$. or more above the iso-electric line), (3) an $\mathrm{M}$ or $\mathrm{W}$ type of QRS complexes, or (4) inverted T waves-criteria which Wood and Wolferth (1939) have agreed to very recently. Observations on serial changes were not included as a part of this study.

\section{METHOD AND RESULTS}

The right arm electrode was placed $5 \mathrm{~cm}$. to the left of the midsternal line in the fourth interspace. The other electrode was led off from the left leg. This derivation of the præcordial lead corresponds to the mirror image of the $\mathrm{CF}_{3}$ lead which Wood and Wolferth (1939) in their most recent review consider very useful and reliable.* Small monel metal electrodes ( 1 inch in diameter) with salt paste were used.

* Since January 1938, following the suggestion of the American Heart Association, we have been taking the præcordial lead with the $\mathbf{R}-\mathbf{A}$ electrode attached to the left leg and the L-A electrode to the præcordium. Throughout this paper the description of the præcordial lead is as if it were taken in this direction. In the figures both the old method of taking the electrocardiogram, and its mirror image, the new $\mathrm{CF}_{3}$ lead, are shown. 
Of the 4000 records studied, duplication reduced the total number of cases to be reviewed to 3200 . Seventy of these $(2 \cdot 2$ per cent) showed præcordial lead abnormality without significant changes in the standard leads. One third of this original group of 70 was finally chosen because of the completeness of clinical detail for analysis in the present study.

After thorough review of the clinical history, physical examination, and radiological findings, the 23 cases were divided into a cardiac and a non-cardiac group, details of which are shown in the tables.

\section{Cardiac Group}

The cardiac group consisted of 13 cases; 10 of these (77 per cent) were females. Details are shown in Fig. 1 and Table I. Only 1 had acute coronary

TABLE I

Electrocardiographic Findings in 13 Cardiac Cases

\begin{tabular}{|c|c|c|c|c|}
\hline Diagnosis & Age at & nd Sex & $\begin{array}{l}\text { Axis Deviation } \\
\text { and Changes in } \\
\text { Standard Leads }\end{array}$ & Changes in Lead $\mathrm{CF}_{3}$ \\
\hline $\begin{array}{l}\text { 1. Coronary thrombosis } \\
\text { and empyema of gall } \\
\text { bladder }\end{array}$ & 62 & $\mathbf{F}$ & $\begin{array}{l}\text { Sl. depressed RS-T } \\
\text { Slurred QRS }_{2} *\end{array}$ & $\begin{array}{l}\text { Small R } \\
\text { Slurred QRS }\end{array}$ \\
\hline $\begin{array}{l}\text { 2. Coronary sclerosis and } \\
\text { hypertension }\end{array}$ & 58 & $\mathrm{~F}$ & $\begin{array}{l}\text { Sl. slurred } \mathrm{QRS}_{2} \\
\text { Inverted } \mathrm{T}_{3} *\end{array}$ & $\begin{array}{l}\text { Absent R } \\
\text { Cove-planed T }\end{array}$ \\
\hline $\begin{array}{l}\text { 3. Coronary sclerosis and } \\
\text { hypertension }\end{array}$ & 65 & M & Slurred QRS Q $_{1}^{*}$ & $\begin{array}{l}\text { Absent R } \\
\text { W-type QRS }\end{array}$ \\
\hline $\begin{array}{l}\text { 4. Rheumatic mitral } \\
\text { stenosis }\end{array}$ & 18 & $\mathrm{~F}$ & $\begin{array}{l}\text { Inverted } \mathbf{P}_{3} \\
\text { Biphasic } \mathrm{T}_{3}\end{array}$ & Inverted $\mathrm{T}$ \\
\hline $\begin{array}{l}\text { 5. Arteriosclerotic heart } \\
\text { disease }\end{array}$ & 53 & $\mathrm{~F}$ & Inverted $\mathrm{T}_{3} *$ & $\begin{array}{l}\text { M-type QRS } \\
\text { Inverted } T\end{array}$ \\
\hline 6. Essential hypertension & 60 & F & $\begin{array}{l}\text { Sl. depressed RS-T } \\
\text { Small, biphasic } \mathrm{T}_{3}\end{array}$ & $\begin{array}{l}\text { Small QRS } \\
\text { Inverted T }\end{array}$ \\
\hline $\begin{array}{l}\text { 7. Essential hypertension } \\
\text { and diabetes }\end{array}$ & 38 & $\mathrm{~F}$ & $\begin{array}{l}\text { Small QRS } \\
\text { Low, biphasic } \mathrm{T}_{3} .\end{array}$ & $\begin{array}{l}\text { Sl. elevated RS-T } \\
\text { Rel. small R } \\
\text { Sl. inverted T }\end{array}$ \\
\hline $\begin{array}{l}\text { 8. Nephritis, hypertension, } \\
\text { and pregnancy }\end{array}$ & 41 & $\mathrm{~F}$ & Small QRS $_{3}$ & $\begin{array}{l}\text { Very small R } \\
\text { Monophasic, slurred }\end{array}$ \\
\hline $\begin{array}{l}\text { 9. Luetic aortitis and } \\
\text { cirrhosis }\end{array}$ & 56 & M & $\begin{array}{l}\text { Slurred } Q R S_{2 \text { and } 3} \\
\text { Prominent } S_{2}^{*}\end{array}$ & $\begin{array}{l}\text { Absent R } \\
\text { Unusual QRS }\end{array}$ \\
\hline 10. Hyperthyroidism $\quad \ldots$ & 64 & $\mathbf{M}$ & Slight tachycardia * & Absent $R$, unusual QRS \\
\hline $\begin{array}{l}\text { 11. Unknown cardiac } \\
\text { disease }\end{array}$ & 44 & $\mathrm{~F}$ & $\begin{array}{l}\mathrm{Q}_{2} \text { and } \mathrm{Q}_{3} \text { present } \\
\text { Slurred } \mathrm{QRS}\end{array}$ & $\begin{array}{l}\text { Inverted T } \\
\text { Small, slurred QRS }\end{array}$ \\
\hline $\begin{array}{l}\text { 12. Unknown cardiac } \\
\text { disease }\end{array}$ & 38 & $\mathrm{~F}$ & $\begin{array}{l}\text { Low-voltage } \mathrm{QRS}_{3} \\
\text { Inverted } \mathrm{T}_{3}\end{array}$ & $\begin{array}{l}\text { Absent R } \\
\text { Monophasic QRS }\end{array}$ \\
\hline $\begin{array}{l}\text { 13. Unknown cardiac } \\
\text { disease }\end{array}$ & 46 & $\mathrm{~F}$ & Low $\mathrm{QRS}_{3}$ & $\begin{array}{l}\text { Small R } \\
\text { Inverted T }\end{array}$ \\
\hline
\end{tabular}

* Left axis deviation. 


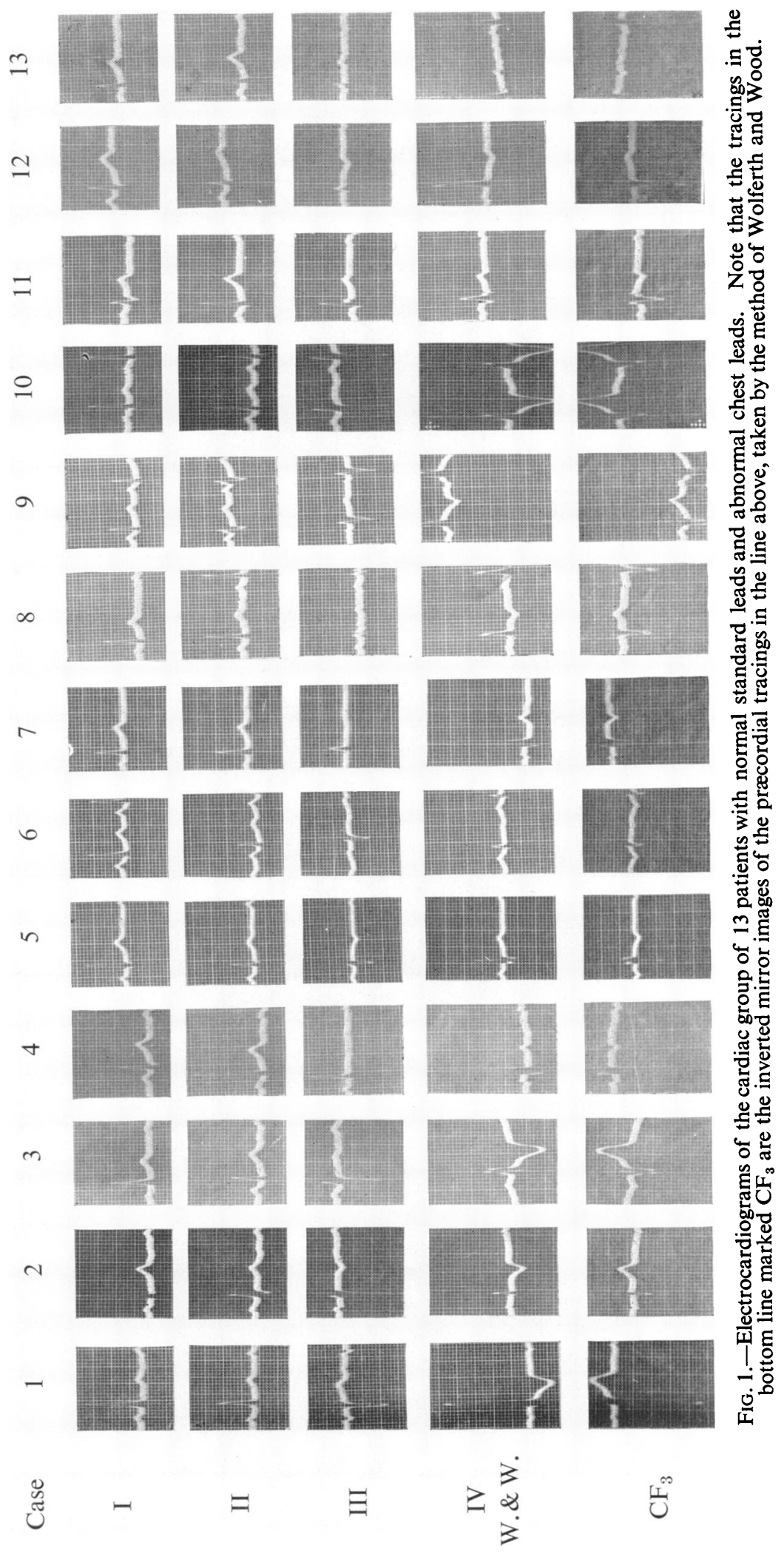

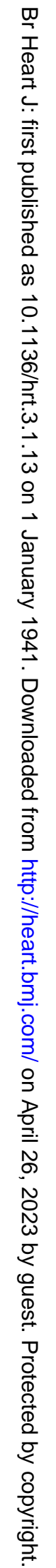


thrombosis, and only 2 others suffered from coronary sclerosis. Left axis deviation was present in 7 patients. The initial upward deflection ( $\mathrm{R}$ wave) * was absent in 5 cases, 3 of which were accompanied by left axis deviation; it was small (less than $2 \mathrm{~mm}$.) in 5 patients: in no case in which the $R$ wave was absent was there an inverted $\mathrm{T}$ wave. QRS complexes of $\mathrm{M}$ and $\mathrm{W}$ type occurred in 2 cases. The $T$ wave was inverted in 5 cases. All the 5 tracings in which the initial upward deflection ( $R$ wave) was small showed inverted $T$ waves. In one patient a cove-planed $\mathrm{T}$ accompanied an almost absent $\mathrm{R}$ wave. The most common finding in this cardiac group was an absent $R$ wave (38 per cent), or a small $R$ wave (38 per cent).

\section{Non-Cardiac Group}

In this group of 10 cases (43 per cent), 8 were females. Diseases of the lungs contributed the greatest number of cases to this division. Details are shown in Table II and Fig. 2. Left axis deviation occurred in 4 cases. In contrast to the previous group the initial upward deflection ( $R$ wave) was absent only once (a man of 74 with adenocarcinoma of the sigmoid in whom coronary disease could not with certainty be ruled out clinically; for lack of positive evidence, however, we put him in the non-cardiac group). A small $R$ wave occurred in 4 cases, and this was always accompanied by inverted or biphasic $T$ waves. The $T$ wave was inverted in 6 and biphasic in 3 cases. Thus the characteristic positive finding of the non-cardiacs was $T$ wave inversion.

TABLE II

Electrocardiographic Findings in 10 Non-Cardiac Cases

\begin{tabular}{|c|c|c|c|c|}
\hline Diagnosis & \multicolumn{2}{|c|}{ Age and Sex } & $\begin{array}{l}\text { Axis Deviation and } \\
\text { Changes in } \\
\text { Standard Leads }\end{array}$ & Changes in Lead $\mathrm{CF}_{3}$ \\
\hline $\begin{array}{l}\text { 14. Carcinoma of left } \\
\text { bronchus }\end{array}$ & & $\mathbf{M}$ & $\begin{array}{l}\text { Small } Q_{2} \text { and 3, low } T_{3} \\
\text { Slurred } Q R S \text {, prom. } S_{1}\end{array}$ & $\begin{array}{l}\text { Inverted T } \\
\text { Slurred QRS }\end{array}$ \\
\hline 15. Broncho-pneumonia & 50 & $\mathbf{F}$ & Flat $T_{3}$ & $\begin{array}{l}\text { Low R } \\
\text { Small, flat } T\end{array}$ \\
\hline $\begin{array}{l}\text { 16. Broncho-pneumonia } \\
\text { and diabetes }\end{array}$ & 57 & $\mathrm{~F}$ & $\begin{array}{l}\text { Slurred } Q R S \\
\text { Inverted } T_{3} \dagger\end{array}$ & $\begin{array}{l}\text { Small inverted T } \\
\text { Small QRS }\end{array}$ \\
\hline 17. Neoplasm of right lung & 44 & F & $\begin{array}{l}\text { Sl. depr. RS-T }{ }_{1}, 2,3 \\
\text { Low } \mathrm{QRS}_{3}\end{array}$ & $\begin{array}{l}\text { Low R } \\
\text { Small inverted T }\end{array}$ \\
\hline 18. Pregnancy $\quad .$. & 29 & $\mathbf{F}$ & $\begin{array}{l}\text { M-shaped QRS, } \\
\mathrm{S}_{1} \text { present, Inverted } \mathrm{T}_{3}\end{array}$ & Inverted $\mathbf{T}$ \\
\hline 19. Pregnancy .. & 21 & F & Inverted $T_{3}$ & Low biphasic $T$ \\
\hline 20. Pylorospasm & 54 & F & $\begin{array}{l}\text { Small } \mathrm{QRS}_{3} \\
\text { Flat } \mathrm{T}_{3}\end{array}$ & $\begin{array}{l}\text { Small } R \\
\text { Small inverted } \mathrm{T}\end{array}$ \\
\hline 21. Chronic cholecystitis.. & 52 & F & $\begin{array}{l}\text { Sl. diphasic } T_{1}, 2,3 \\
Q_{3} \text { present } \\
{\text { Small } Q_{2} S_{3}} \uparrow\end{array}$ & $\begin{array}{l}\text { Small R } \\
\text { Biphasic T }\end{array}$ \\
\hline $\begin{array}{l}\text { 22. Adenocarcinoma of } \\
\text { sigmoid }\end{array}$ & 74 & $\mathbf{M}$ & Sl. slurring $\mathrm{QRS}_{2},{ }_{3} \dagger$ & $\begin{array}{l}\text { Absent R } \\
\text { Cove-planed T }\end{array}$ \\
\hline $\begin{array}{l}\text { 23. Spinal deformity and } \\
\text { polyneuritis }\end{array}$ & 18 & $\mathbf{F}$ & Biphasic $T_{3}$ & Inverted T \\
\hline
\end{tabular}

* See note on p. 13.

$\dagger$ Left axis deviation. 


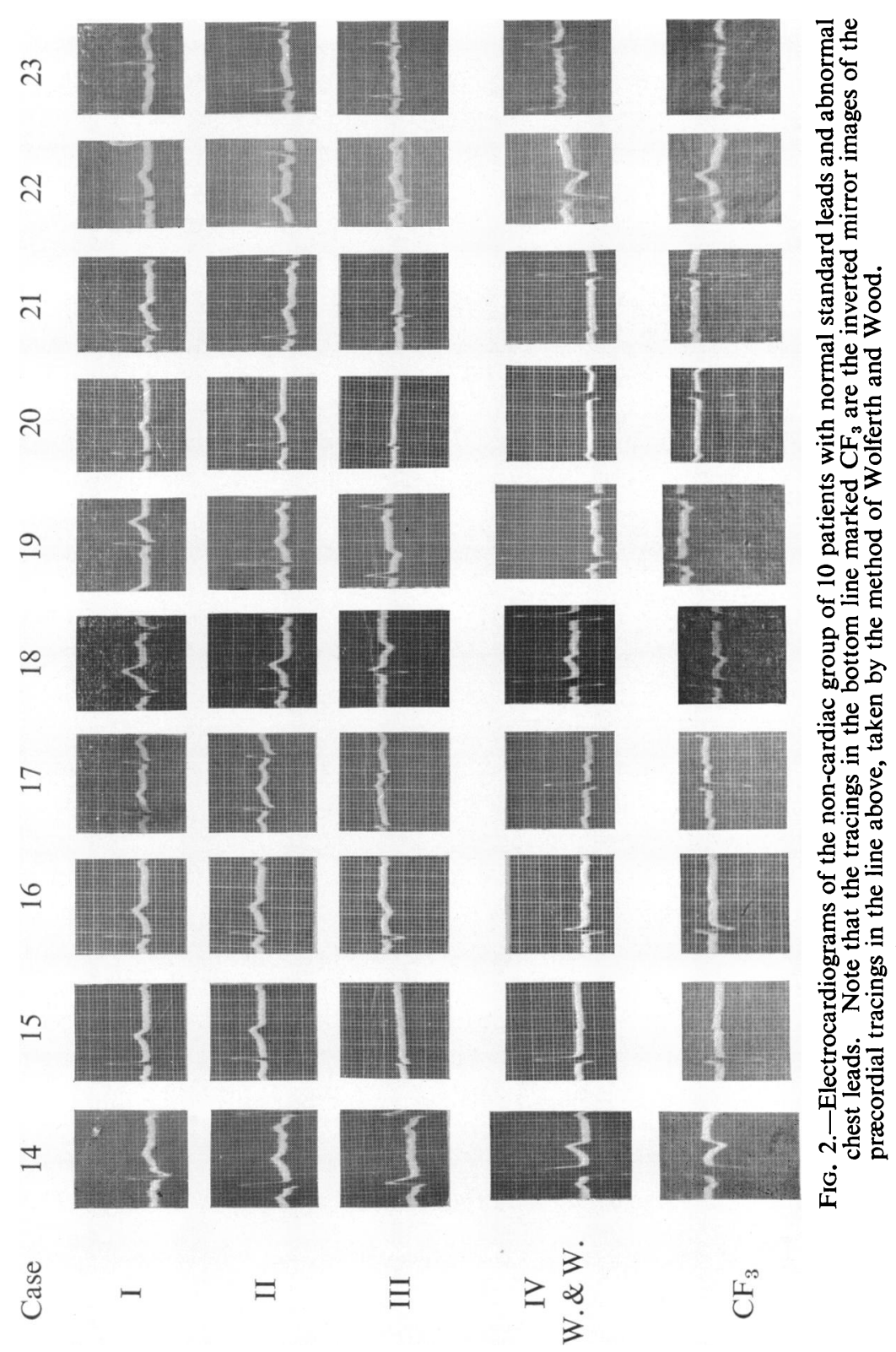

C 


\section{Discussion}

To assay the significance of any lead in the diagnosis of heart disease is very difficult, since dogmatic statements in any single case cannot be made before necropsy is performed. With relatively limited autopsy material available, reliance had to be placed on clinical history, physical examination, and radiology (Note that for obvious reasons of logic, we could not even use the electrocardiograms in this study to help determine which of our cases were cardiac and which non-cardiac.) For this reason we have included in our analysis only those cases in which the charts were complete enough to give a full history and the physical and radiological features of the case. Where any doubt existed the patient was recalled for re-examination.

An analysis reveals that 5 of the 6 cases in which $R_{4}$ was absent were in the cardiac group, and the sixth, who was a man of 74 , may well have had coronary sclerosis. It therefore follows that an absent $\mathrm{R}_{4}$ is the most important single evidence of myocardial disease. We cannot, however, agree with Levine and Levine (1936) who consider an absent $R_{4}$ wave as positive evidence for myocardial infarction, since this condition was present in only 1 of our 5 cases with an absent $R_{4}$. As has been previously reported by Master et al (1937), this finding indicates heart disease in general, but does not determine the exact nature of the pathological process.

Further study of the 23 positive fourth lead cases showed that small $\mathrm{R}$ waves were seen as frequently in the non-cardiac as in the cardiac group. No significant $T$ wave aberrations occurred in either group. We could not determine accurately whether or not small $R$ waves or biphasic or inverted $T$ waves in the fourth lead betokened myocardial damage, when the conventional leads were normal. The incidence of a small $R$ wave in 5 cases of the cardiac and in 5 cases of the non-cardiac group suggests, however, that this single finding in the fourth lead does not indicate myocardial disease. As for the $\mathrm{T}_{4}$ wave abnormalities, the chart shows 6 cases with inverted $T$ waves in the cardiac, and 5 cases in the non-cardiac group. This agrees with Levine and Levine's report (1936) of inverted $\mathrm{T}$ waves in adults where there was no significant heart disease, and disagrees with Edeiken et al. (1936) who feel that adult cases showing an abnormal præcordial $\mathrm{T}$ wave as the only significant electrocardiographic finding have angina pectoris or a history of coronary occlusion.

The great number of females in both groups (18 out of 23 , i.e. 78 per cent), seemed rather striking, in view of the fact that the præcordial lead changes have up to now been most frequently reported as accompanying coronary thrombosis or sclerosis-conditions which predominantly affect the male sex. (The ratio of more than 3 females to 1 male in this series differs from the general ratio of about 1 to 1 , observed in this electrocardiographic department. No comprehensive reports comparing præcordial leads in males and females have been found. Shipley and Hallaran (1936) compared 200 normal men and women, but the ages varied from 20 to 35 years, whereas the mean age for the females of our series was 44 years. Since the cardiographic aberrations incident to pregnancy are reversible (Landt and Benjamin, 1936), we do not feel that 
they could have played a significant role in this group, except possibly for Cases 18 and 19. Abdominal obesity, however, by causing changes similar to those that obtain in pregnancy may have been a factor in shifting the heart's axis, thus accounting for the $T$ wave inversion.

\section{SUMmARY AND CONCLUSIONS}

Four thousand four-lead electrocardiograms (3200 cases) were reviewed to assess the diagnostic value of an abnormal præcordial lead when the standard leads were normal. The criteria adhered to as a basis for this selection were an absent $\mathrm{R}$ wave, an $\mathrm{R}$ wave of less than $2 \mathrm{~mm}$., a QRS wave of $\mathrm{M}$ or $\mathrm{W}$ configuration, or an inverted $T$ wave-these being found in the fourth lead, in the presence of standard leads that were without significant alterations. Of the 3200 cases 70 showed positive præcordial and negative standard leads. Of these 70 a characteristic group of 23 was completely analysed as representative of the larger group. By careful history, physical examination, and X-ray the 23 cases with positive chest leads were divided into a cardiac group (57 per cent) and a non-cardiac group (43 per cent). Left axis deviation occurred with about equal frequency in both groups. In the cardiac group, coronary thrombosis was present only once ( 8 per cent). Pulmonary disease contributed the greatest number of cases to the non-cardiac group (4 out of 10). Absence of the initial upward deflection ( $R$ wave) in lead $I V$ was the most common finding in the cardiac group (5 out of 13 cases). Low $\mathrm{R}$ waves occurred with about equal frequency in both groups. Inverted or biphasic $\mathrm{T}$ waves were present slightly more often in the non-cardiac than in the cardiac group. The female sex was predominant in the ratio of about 3 to 1 in both groups.

Where the standard leads were normal the præcordial lead was the sole electrocardiographic indicator of heart disease in 1.2 per cent of 3200 cases studied. An abnormal fourth lead in the presence of normal standard leads is indicative of heart disease in more than 50 per cent of such cases.

An absent $R$ wave is of greater significance as a sign of myocardial damage than are either low $R$ waves or inverted $T$ waves, alone or combined.

The præcordial lead may be the only electrocardiographic evidence of heart disease in conditions other than coronary thrombosis or sclerosis.

The authors are deeply indebted to Dr. Harry Vesell, Director of the Electrocardiographic Department, for his co-operation in this study; and to Mrs. F. Moore, the electrocardiographic technician, who helped to prepare the tracings for publication.

\section{REFERENCES}

Edeiken, J., Wolferth, C. C., and Wood, F. C. (1936). Amer. Heart J., 12, 666.

Goldbloom, A. A. (1934). Amer. J. med. Sci., 187, 489.

Hoffman, A. M., and DeLong, E. (1933). Arch. intern. Med., 51, 947.

Katz, L. N., and Kissin, M. (1933). Amer. Heart J., 8, 595.

Landt, H., and Benjamin, J. E. (1936). Amer. Heart J., 12, 592.

Levine, D., and Levine, S. A. (1936). Amer. J. med. Sci., 191, 98. 
Lieberson, A., and Lieberson, F. (1932-33). Ann. intern. Med., 6, 1315.

Master, A. M. (1934). Amer. Heart J., 9, 511.

Dack, S., Kalter, H. H., and Jaffe, H. L. (1937). Amer. Heart J., 14, 297.

Shipley, R. A., and Hallaran, W. R. (1936). Amer. Heart J., 11, 325.

Wilson, F. N., Barker, P. S., MacLeod, A. G., and Klostermyer, L. L. (1931-32). Proc. Soc. exp. Biol. and Med., 29, 1006.

Wolferth, C. C., and Wood, F. C. (1932). Amer. J. med. Sci., 183, 30.

Wood, F. C., and Wolferth, C. C. (1939). Amer. Heart Assoc., 8, 1. 